ББК 63.4

\author{
Организация конференциии и издание материалов проведень \\ при финансовой поддержке Российского фонда фундаментальных исследований, \\ проект № 19-09-20008
}

Утверждено к печати Ученым советом ИИМК РАН

Редакционная коллегия тома I: В. А. Алёкшин, Л. Б. Кирчо (отв. редакторы),

В. П. Никоноров, В. Я. Стёганцева; В. В. Терёхина

Рецензенты: д. и. н. Л. Б. Вишняцкий, д. и. н. А. А. Выборнов

Программный комитет конференции: академик РАН, д. и. н., проф. М. Б. Пиотровский

(Государственный Эрмитаж, почетный председатель); д. и. н. В. А. Лапшин (ИИМК РАН, председатель); д. и. н. А. В. Головнёв (МАЭ РАН, сопредседатель); д. и. н. В. А. Дергачёв (Высшая антропологическая школа, Молдова, сопредседатель); д. и. н. И. Ф. Попова (ИВР РАН, сопредседатель); академик АН Республики Узбекистан, д. и. н., проф. Э. В. Ртвеладзе (сопредседатель); к. и. н. А. В. Поляков (ИИМК РАН, зам. председателя); к. и. н. В. А. Алёкшин (ИИМК РАН, зам. председателя); д. и. н. Ю. Е. Берёзкин (МАЭ РАН); Dr., Prof. Н. Бороффка (Германский археологический институт, Германия); В. С. Бочкарёв (ИИМК РАН); Dr. Э. Кайзер (Свободный университет Берлина, Германия); к. и. н. М. Т. Кашуба (ИИМК РАН); д. и. н. Л. Б. Кирчо (ИИМК РАН); к. и. н. А. В. Кияшко (Южный федеральный университет); к. и. н. П. Ф. Кузнецов (СГСПУ);

к. и. н. Н. М. Малов (СНИГУ); к. и. н. В. П. Никоноров (ИИМК РАН); Ю. Ю. Пиотровский

(Государственный Эрмитаж); д. и. н., проф. Д. Г. Савинов (Институт истории СПбГУ);

к. и. н. В. Н. Седых (Институт истории СПбГУ); к. и. н. Н. Н. Скакун (ИИМК РАН);

к. и. н. Н. Ф. Соловьёва (ИИМК РАН); к. и. н. А. И. Торгоев (Государственный Эрмитаж); к. и. н. Е. А. Черлёнок (Институт истории СПбГУ)

Организационный комитет конференции: к. и. н. А. В. Поляков (ИИМК РАН, председатель);

к. и. н. В. А. Алёкшин (ИИМК РАН, зам. председателя); В. С. Бочкарёв (ИИМК РАН); ); к. и. н. М. Т. Кашуба (ИИМК РАН); д. и. н. Л. Б. Кирчо (ИИМК РАН);

А. И. Климушина (ИИМК РАН, отв. секретарь); к. и. н. В. П. Никоноров (ИИМК РАН); Ю. Ю. Пиотровский (Государственный Эрмитаж); В. Я. Стёганцева (ИИМК РАН); В. В. Терёхина

(ИИМК РАН, МАЭ РАН, отв. секретарь); к. и. н. Е. С. Ткач (ИИМК РАН); И. Ж. Тутаева (Государственный Эрмитаж); к. и. н. Е. А. Черлёнок (Институт истории СПбГУ)

Древности Восточной Европы, Центральной Азии и Южной Сибири в контексте связей и взаимодействий в евразийском культурном пространстве (новые данные и концепции): Материалы Международной конференции, 18-22 ноября 2019 г., Санкт-Петербург. Т. I. Древняя Центральная Азия в контексте евразийского культурного пространства (новые данные и концепции). К 90-летию со дня рождения патриарха евразийской археологии Вадима Михайловича Массона. - СПб.: ИИМК РАН, Невская Типография, 2019. — 291 с.

ISBN 978-5-907053-34-2

DOI 10.31600/978-5-907053-34-2 
Маргулан А. Х. 1979 Бегазы-дандыбаевская культура Центрального Казахстана. Алма-Ата.

Потемкина Т. М. 2011. Мегалитические сооружения Урала: структура сакрального пространства // Вестник археологии, антропологии и этнографии. 2 (15). С. 11-35.

Hammer E. 2014. Local landscape organization of mobile pastoralists in southeastern Turkey // Journal of Anthropological Archaeology. 35. P. 269-288.

Luneau E. 2017. Transfers and Interactions between North and South in Central Asia during the Bronze Age // Allinger E., Grenet F., Jahoda C., Lang M.-K., Vergati A. (eds.). Interaction in the Himalayas and Central Asia: Processes of Transfer, Translation and Transformation in Art, Archaeology, Religion and Polity, Proceedings of the Third International SEECHAC Colloquium. Vienna. P. 13-23.

\section{ПРЕДВАРИТЕЛЬНЫЕ РЕЗУЛЬТАТЫ НОВЫХ АРХЕОЛОГИЧЕСКИХ ИССЛЕДОВАНИЙ В ГОРАХ НУРАТАУ, УЗБЕКИСТАН}

\section{Э. Люно ${ }^{\star}$, Н. А. Аванесова ${ }^{\star *}$}

* Германский археологический институт, Евразийский отдел, Берлин, Германия; ${ }^{* *}$ Самаркандский государственный университет, Самарканд, Узбекистан

Ключевые слова: Центральная Азия, Узбекистан, горы Нуратау, бронзовый век, ландиафтная археология, схема расселения, ГИС, разведки.

В докладе представлены предварительные результаты новых исследований, проведенных в горах Нуратау (Узбекистан). Эта невысокая горная область ранее не исследовалась на предмет изучения системы расселения. Тем не менее, регион показал высокий потенциал для выявления плотного его обживания в бронзовом веке и для изучения взаимодействия между различными группами людей в это время. Используя спутниковые снимки, полеты беспилотников и пешие разведки, а также геоморфологические исследования, уже первые сезоны полевых работ позволили обнаружить многочисленные следы древнего обживания и землепользования. Статистический и пространственный анализы также дают важные предварительные данные о схемах распределения и структуризации различных поселений и сооружений в этой области на протяжении длительного времени.

\section{ПРИЗНАКИ КУЛЬТУРНОГО ВЗАИМОДЕЙСТВИЯ В АРХЕОЛОГИЧЕСКИХ МАТЕРИАЛАХ ЭПОХИ БРОНЗЫ ТАДЖИКИСТАНА ${ }^{1}$}

Ю. Г. Кутимов ${ }^{\star}$, Э. Люно ${ }^{\star *}$

* Институт истории материальной культуры РАН, Санкт-Петербург, Россия;

** Германский археологический институт, Евразийский отдел, Берлин, Германия

DOI: 10.31600/978-5-907053-34-2-237-239

Ключевые слова: Таджикистан, бронзовый век, культурные контакты.

Бронзовый век на территории Центральной Азии характеризуется активным культурным взаимодействием различных по происхождению, образу жизни, хозяйственной деятельности и уровню развития материальной культуры местных оседлых и пришлых

\footnotetext{
${ }^{1}$ Работа выполнена в рамках программы ФНИ ГАН по теме государственного задания № 01842019-0003 «Генезис древних цивилизаций Центральной Азии (V тыс. до н. э. - I тыс. н. э.) и их взаимодействие с земледельческими центрами Среднего Востока и пастушескими (кочевническими) обществами степной зоны Евразии».
} 
степных групп населения. В настоящее время на территории Центральной Азии известно значительное число археологических комплексов степного типа, свидетельствующих об активных миграциях номадов из зоны Евразийских степей и освоении ими глубинных районов Центральной Азии.

Одним из наиболее интересных регионов Центральной Азии в плане исследования культурных связей и взаимодействия разнородных групп населения является территория современного Таджикистана. Наибольшее число археологических комплексов бронзового века Таджикистана относится к памятникам древнеземледельческой культуры, появление которых здесь связано с миграционным распространением населения в IV-II тыс. до н. э. из различных древнеземледельческих центров Центральной Азии, Афганистана и Ирана. Одновременно с миграциями древнеземледельческого населения, во II тыс. до н. э. на территорию Таджикистана из степной зоны Евразии приходят группы андроновских племен фёдоровского типа. Своеобразная культурная группа мобильного населения, обитавшего на территории Таджикистана в эпоху поздней бронзы, представлена памятниками бишкентско-вахшской культуры, возникновение которой связано с процессом выделения отдельных групп племен из среды древних земледельцев Северного Афганистана и Южного Узбекистана. Заключительный период бронзового века на территории Центральной Азии, в том числе и Таджикистана, связан с распространением общности культур лепной расписной керамики (типа Яз I).

Происхождение данных культур носит нелокальный характер, все они появились на территории Таджикистана в результате широкомасштабных миграционных передвижений разнообразных культурных групп населения из различных регионов Евразии, пришедших сюда и обитавших здесь в условиях значительного удаления или даже в отрыве от своей основной территории обитания. В процессе жизнедеятельности на территории Таджикистана данные группы населения вступали друг с другом в активное культурное, социальное и хозяйственное взаимодействие. Особенно заметно данный процесс отражается в археологических материалах позднего бронзового века.

Одной из наиболее активных зон культурных контактов в эпоху поздней бронзы на территории Таджикистана являются западные районы Гиссарской долины. С 2012 г. по настоящее время здесь проводятся археологические исследования памятников бронзового века, в ходе которых получены новые материалы, свидетельствующие об активных контактах различных культурных групп населения - местного оседло-земледельческого и степного андроновского. В числе особо ярких и интересных находок следует отметить археологические материалы из могильников позднего бронзового века Кумсай и Тандырйул, которые демонстрируют высокий уровень культурного взаимодействия, как в сфере погребального обряда, так и плане заимствования отдельных технико-технологических и орнаментальных принципов изготовления керамической посуды.

\title{
MARKERS OF CULTURAL INTERACTION IN ARCHAEOLOGICAL MATERIALS OF THE BRONZE AGE OF TAJIKISTAN
}

\author{
Yuri G. Kutimov ${ }^{\star}$, Elise Luneau ${ }^{* *}$ \\ ${ }^{*}$ Institute for the History of Material Culture of the Russian Academy of Sciences, St. Petersburg, \\ Russia; ${ }^{* *}$ German Archaeological Institute, Berlin, Germany
}

Keywords: Tajikistan, Bronze Age, cultural contacts.

One of the most active areas of cultural contacts in the Late Bronze Age in Tajikistan was the western part of the Hissar Valley. Since 2012 to the present the archaeological excavations at sites of the Bronze Age are carried out here. During these investigations the new materials were obtained that 
testify to active contacts between various cultural groups of the population - the local settled agriculturalists and the Andronovo steppe people. The most striking and interesting finds came from the Late Bronze Age burial grounds of Kumsay and Tandyryul. These materials demonstrate a high level of cultural interaction, both in the sphere of funerary rites and in borrowing some technological and ornamental principles for the ceramic production.

\title{
РАБОТЫ ПО ПРОЕКТУ «NOMAD STATE FORMATION AND URBANIZATION: THE EARLY MEDIEVAL TOWN OF DZHANKENT (ARAL SEA REGION, KAZAKHSTAN)"
}

\author{
И. А. Аржанцева ${ }^{\star}$, Г. Х. Херке ${ }^{\star *}$, А. Тажекеев ${ }^{\star * *}$ \\ ${ }^{*}$ Институт этнологии и антропологии РАН; Центр Античной и Восточной архео- \\ тогии Института классического Востока и античности Национального исследова- \\ тельского университета Высшей школы экономики, Москва, Россия; ${ }^{*}$ Тюбингенский \\ университет, Тюбинген, Германия; Центр Античной и Восточной археологии \\ Института классического Востока и античности Национального исследовательского \\ университета Высшей школы экономики, Москва, Россия; ${ }^{* * \star ~ К ы з ы л о р д и н с к и и ̆ ~}$ \\ Государственный университет им. Коркыт Ата, Кызыл-Орда, Казахстан
}

DOI: $10.31600 / 978-5-907053-34-2-239-241$

Ключевые слова: Восточное Приаралье, Джанкент, кочевники, раннее средневековье, города, естественнонаучные методы.

Городище Джанкент принадлежит к группе так называемых болотных городищ. Термин «болотные городища» был впервые введен С. П. Толстовым в 1946 г. для памятников, расположенных в районе старого русла р. Сырдарьи (Казахстан). К «болотным» городищам были отнесены Джанкент, Кескен-Куюк-кала и Большая Куюк-кала. В последние годы интерес к этим памятникам возобновился. Их исследование стало одним из приоритетных направлений в средневековой археологии Казахстана, так как именно этот регион и «болотные» городища с большой долей вероятности связывают с огузами, причем Джанкент считается резиденцией царя огузов (Толстов 1947: 56; Бартольд 1963: 235; Байпаков 2007: $51,52)$.

Основные работы по проекту сосредоточены на указанном городище (рис. 1), так как именно оно упоминалось несколько раз в письменных источниках как крупный торговый центр и порт, а также в качестве вероятной ставки огузского ябгу (сообщения Ибн-Русте, Ибн Хаукал, Ал-Макдаси - Струве 1939: 150, 184, 217).

Крупномасштабные работы на памятнике начались в 2005 г. (Аржанцева, Тажекеев 2014), но только в 2011 г. приступили к широкому применению междисциплинарных методов исследования, давших обширную информацию по истории возникновения, функционирования, планировке, структуре и датировке Джанкента.

Полученные в ходе многолетних работ материалы позволяют возобновить дискуссию о хронологии, происхождении и роли «болотных» городищ в раннесредневековой и средневековой истории не только Приаралья, но и Юго-Восточной России.

Цели и основные задачи настоящего проекта, который начат в 2018 г., находятся в центре нескольких дискуссий, представляющих значительный интерес: степная урбанизация, кочевые государства, опустынивание в восточной части региона Аральского моря и изменение стока дельтовых русел Сыр-Дарьи.

Массовый материал с городища Джанкент датируется в основном IX-X вв. Тем не менее, радиокарбоновые даты нижних слоев, полученные при бурении культурного слоя 